\title{
Addressing Iraqi EFL Teacher/Learner Discourse Interactions in Task-Based Classrooms
}

\author{
Bushra Ni'ma Rashid \\ English Department Ibn Rushd College University of Baghdad \\ Baghdad, Iraq \\ E-mail: bosh.1969bosh@yahoo.com
}

Doi:10.7575/aiac.alls.v.5n.6p.204

Received: 28/08/2014

URL: http://dx.doi.org/10.7575/aiac.alls.v.5n.6p.204

Accepted: 20/10/2014

\begin{abstract}
Teaching English in an EFL context involves certain difficulties. The most important is how to prepare learners to use the English language so as to be able to participate in conversations inside and outside the class. Six classes at intermediate level (nine hours) were video and audio-taped in their entirety. The study explored recurring patterns of questioning behavior and their interactive effects were observed through nonparticipant observation. The findings of this study indicated that Display questions were used by the teachers more frequently than Referential questions. Also, it was concluded that NOT all Referential questions could create enough interaction.
\end{abstract}

Keywords: Display/Referential questions, classroom observation.

\section{Introduction}

Communication includes both verbal (that is, language in written and spoken form) and non-verbal (that is, language in conventional symbols and ways of representation through drawing and diagrams) forms.

One of the principal means through which patterns of interaction are constructed is language. To interpret the patterns of life, members need to process linguistic and non-verbal aspects of the social interactions of others. Language, in relationship to the social construction of life in classrooms, refers to the oral and written discourse norms, expectations, and strategies that members establish through their daily interactions.

Communication is called for when the language user recognizes a situation which requires the conveyance of information to establish a convergence of knowledge, so that this situation can be changed in some way. This transaction requires the negotiation of meaning through interaction. I refer to this negotiation as discourse (Widdowson, 1984: 100).

Classroom Discourse is a special type of discourse that occurs in classrooms. Special features of classroom discourse include: unequal power relationships, turn-taking at speaking, patterns of interaction, etc. Classroom discourse is often different in form and function from language used in other situations because of particular social roles which learners and teachers have in classrooms and the kind of activities they usually carry out there.

One of the influential factors in creating classroom interactions is the types of the questions which are asked by the teachers. The two common question types are: Display and Referential questions. Based on many studies, Referential questions make for more interaction and meaningful negotiation. According to Brown (2001), Display Questions refer to questions for which the teacher knows the answers and demand a single or short response. By contrast, Referential Questions demand more thought and generates longer responses.

\section{Review of the related literature}

\subsection{Classroom Discourse: an Overview}

The concept of language classroom discourse has undergone various interpretations.

Nunan (1993) views classroom discourse as "the distinctive type of discourse that occurs in classrooms". Discourse in the language classroom is a matter of the oral use of language in the classrooms. At least 40 years ago, an important direction in applied linguistics and education research sought to understand the nature and implications of classroom interactions, or what is commonly referred to as "classroom discourse".

One influential approach to the study of spoken discourse, as acknowledged by (McCarthy, 1991), was carried out by Sinclair and Coulthard (1975) at the University of Birmingham. Sinclair and Coulthard suggested a three tier approach, beginning-middle-end, to focus on the distinct "moves" that take place in discourse, which can be considered as question-answer-comment in the classroom environment, or command-acknowledgement-polite formality, as occurs in a shop between the client and the shopkeeper. 
Broadly speaking, classroom studies can be viewed from three different perspectives (Johnson and Johnson, 1998):

1. From the perspective of interaction (between teacher/learners with each other)

2. From the perspective of the effects of instruction on language development.

3. From the perspective of whether different methods of instruction have different effects on language development.

According to (Chang, 1999: 2-3), discourse in a classroom can be divided into four structures as follows: 1. IRF (Initiation-Response-Feedback), 2. Instruction 3. Probing Questions 4. Argumentation.

\section{IRF}

IRF may have a traditional pattern of discourse, when the teacher asks a question, the student answers and the teacher evaluates. The teacher continues to ask another question and so the sequence continues. "In this typical three-part structure, the teacher initiates a question in order to check a student's knowledge, a student's responses, and the student's response is evaluated with feedback from the teacher" (Our focus) (Richards et al., 1992:52). The students' answers are usually brief and students are concerned about giving correct answers that are expected by the teacher. The main role of the teacher is asking questions, but only a few students are actively involved.

\section{Instruction}

Another type of discourse is giving instructions. The teacher gives directive or informative statements. The students do not answer verbally; however, they understand the statements as instructions by following them physically.

\section{Probing Questions}

The probing question is another discourse structure. The teacher

asks Referential questions or "thinking questions" (Brown, 2001: 171) and the students are encouraged to give longer answers through their thinking. Their answers may challenge the teacher's position. However, evaluation does not come immediately after the students' responses.

\section{Argumentation}

Argumentation can be regarded as probing questions where the teacher involves the students in a challenging situation in order to make them to justify their reasons. The questions asked are commonly Referential questions, which try to elicit predictions, explanations and clarification from the students. The argumentation may be in question or statement forms. Mehan (1979, as cited in Ellis, 1990: 88) offered three structural components of a pedagogic discourse:

1. An opening phase where the participants inform each other that they are in fact going to conduct a lesson as opposed to some other activity.

2. An instructional phase where information is exchanged between teacher and students.

3. A closing phase where participants are reminded of what went on in the core of a lesson.

McTear (1975), as cited in Ellis, 1994: 577) observed four types of language use in EFL classroom discourse:

1. Mechanical (i.e. no exchange of meaning is involved),

2. Meaningful (i.e. meaning is contextualized but there is still no new information to be conveyed),

3. Pseudo-communication (i.e. new information is conveyed but in a manner that would be unlikely to occur outside the Classroom),

4. Real communication (i.e. spontaneous speech resulting from the exchange of opinions, jokes, classroom Management, etc.).

Relevant to McTear's argument here about the types of language use is Ellis's (1990: 86) distinction that "pedagogical discourse is believed to be a product of mechanical and meaningful types of language use, whereas natural discourse is believed to result from real communication type of language use" (Ellis, 1990: 86). However, Kramsch (1985, as cited in Ellis, 1990: 86) considers classroom discourse as composed of "a continuum extending from pedagogic to natural discourse poles". The interaction between group members in a classroom moves between the two poles of this continuum consisting of instructional options. Pedagogic discourse occurs when the teacher and the students act out institutional roles, the tasks are concerned with the transmission and reception of information controlled by the teacher and there is a focus on knowledge as product and on accuracy.

\subsection{Studies of Classroom Interaction}

In one study of classroom talk, (Allwright and Bailey, 1991), Long and Sato compared the teachers' and native speakers' use of Display and Referential questions, comprehension checks, clarification checks, and confirmation checks. A number of striking differences emerged:

1. ESL teachers used significantly more Display than Referential questions in the classroom, so there was less real communication going on in classrooms.

2. The teacher used more imperatives, more statements and fewer questions.

3. The teachers' speech was significantly more oriented to the "here and now". 
Pica and Long carried out two studies (as reported by Nunan, 1989: 25). For their first study, they collected ten-minute recorded samples of speech from ten ESL teachers. The researchers found that ESL classroom conversations differed from conversations out of classroom in a number of ways. There was much less negotiation in the classroom; it was due to the fact that teachers tended to ask Display questions. In the second study, Pica and Long worked on the differences between the language of experienced and inexperienced teachers. According to their study, experienced teachers were found to be more fluent, and used more question forms. The study was carried out with four experienced teachers and twenty-four non-native speakers, two of the teachers were trained to incorporate Referential questions into their classroom instruction but the other two were not (Nunan, 1989).

Brock (1986), another study reported by Nunan (1989), found that those teachers who had not been trained to use Referential questions asked 141 questions. Of this 141, only 24 were Referential and 117 were Display questions. But those teachers who were trained to ask Referential questions asked 194 questions. 173 were Referential and only 21 were Display.

Brock concluded from her study that:

Referential questions may increase the amount of speaking learners do in the classroom is relevant to at least one current view of second language acquisition (SLA). Swain (1983), in reporting the results of a study of the acquisition of French by Canadian children in elementary school immersion classrooms, argues that an output may be an important factor in successful SLA (Brock, 1986, cited in Nunan, 1989: 30).

Suter observed three lessons by four teachers in three different classes and counted the number of Display and Referential questions using a tally sheet. After collecting the data and transcribing them, Suter observed in class (a), the teacher asked 31 Display questions and no Referential questions. In class (b), the teacher asked 19 Display questions and 5 Referential questions. In class (c), the teacher asked 67 Display questions and 41 Referential questions. Suter concluded that Referential questions have been shown to be far more effective in initiating interaction. In another part he notes:

The conclusion I have come to personally is that asking questions is neither the only nor the best stimulus to set classroom interaction in motion, but still I am to establish a clearer view of how to provide learners with clearly focused opportunities to communicate in my own classroom as well as in other teaching contexts (Suter, 2001:8).

The material analyzed in Suter's research was recorded in an evening class of adult learners in Switzerland. The class was working with Headway Pre-Intermediate. Two extracts from the lesson were chosen for transcription and analysis. Suter concluded:

To effectuate a discourse analysis on the basis of the "IRF" model has shown to be of personal and professional interest to me from several points of view. It has provided some valuable insights on characteristics of teacher-centered classroom work in general as well as on my own teaching; it made me aware of what actually happens on the level of spoken discourse when I teach and, for example, what my preferred markers are (OK, right). While analyzing the data, I was surprised at how little individual learners have said in the classroom, a fact which did not match my memory of the lesson. ... Therefore the insights gained from the work on the present study will hopefully help not to lose sight of goals related to providing learners with opportunities to use language communicatively in the classroom and the need for the development of respective activities (Suter, 2002:17).

Another study which deserves mentioning here is the one which was carried out in Korea by Oberli (2003). The purpose of his study was to investigate how an experienced teacher in Seoul, Korea, chose to answer the "weak"/"strong" dichotomy with regard to questioning and feedback strategies in his interactive classroom during a 70-minute lesson observed. The question to which the answer would be sought was: What types of questions does he ask and how do these inform his strategies and their effectiveness? Oberli concludes:

The questions investigated have produced some unusual, seemingly conflicting findings ... we have, on the one hand, a teacher who mostly asks convergent questions, often just closed ones. These indicate that he is in "control", "manipulating", classroom interaction in a near "mechanical” way (Oberli, 2003:10).

\subsection{Questions (good/bad questions)}

The Longman Dictionary of English Language provides the following definition for a question: "a command or interrogative expression used to elicit information or a response, or to test knowledge". Lynch (1991, cited in Shomoossi, 2004) characterizes a question as an utterance with a particular illocutionary force; and Quirk et al., (1970, cited in Shomoossi, 2004) define a question as a semantic class used to seek information on a specific subject. Questioning is the single most influential teaching act and the trend has hardly changed over the years. In the realm of teaching and learning, questions have been cited as not only the most often used, but also the single most important strategy used by instructors. 
In order to teach well, a teacher must be able to question well. Asking good questions smoothes the interaction between the teacher and his or her students. Rosenshine (1971, as cited in Brualdi, 1998) found that large amounts of studentteacher interaction promote student achievement.

Teachers spend most of their time asking low-level cognitive questions (Wilen, 1991, cited in Brualdi, 1998). These type of interactions focus on factual information that can be memorized; for example, "When did the First World War start? " or "Who wrote Gone with the Wind? ". It shows that these type of questions limit students, they do not help them to think deeply about the subjects. High-level cognitive questions, in contrast, help students to use higher order thinking or reasoning skills. By using these skills, the students are not forced to memorize only factual knowledge, instead, they use their skills and knowledge to analyze, evaluate and solve the problem. Ellis (1993, cited in Hussain, 2003) claims that many teachers do rely on low-level cognitive questions in order to avoid a slow-paced lesson, keep the attention of the students, and maintain control of the classroom.

\subsection{Effective Questioning}

"Questions and answers ( $\mathrm{Q}$ and $\mathrm{A})$ form a high percentage of classroom activities that are supposed to get the learners involved in creation or recreation of meaning through language" (Chastain, 1988: 142). However not all Q and A's are of communicative value. To be effective, Q and A's should be designed to ask for information. That means in every Q and A activity there must be a communicative purpose and an information gap to be filled. Questions that do not serve that purpose will be little value in language teaching since in reality questions are not asked in vacuums. "As language teachers, our motive in questioning is usually to get our students to engage with the language material activity through speech; so an effective questioning technique is one that elicits fairly prompt, motivated, relevant and full responses" (Ur, 1996: 230).

\subsection{Question Types}

Suter (2001) has proposed the following question types in his article: Socratic or Elicitation Question: A methodological approach which can be found in classrooms is to structure a lesson by hopping from a question to the next one, using the learners' answers as point of departure for the next question. To follow his or her plan, the teacher cannot proceed with the lesson until the expected answer is given by a learner. This approach can be referred to as the "Socratic Method" (Chaudron, 1988:129), or "Elicitation Method" (Nunan, 1991:195).

\subsubsection{Convergent Questions vs. Divergent Questions}

Richards and Lockheart (1996, cited in Suter, 2001) propose to classify questions into either "Convergent" or "Divergent" ones. Richards et al., state that "Convergent is a question that encourages students' responses to focus on a central theme such as convergent questions require a single correct answer and elicit short responses from students" (Richards et al., 1992: 85). Convergent questions are useful when the teacher focuses on certain skills or information, such as when the teacher tries to find out whether learners can focus on specific information in a reading part. Convergent questions can be divided into closed (yes/no answers) and open questions.

Divergent questions allow the learners to establish real personal involvement in the course of the lesson. In other words, "A divergent question is a question that elicits students' responses that vary or diverge"(ibid., p. 115).

Divergent questions are used when the teacher wants to compare students' ideas about a specific topic. There are no wrong answers or right answers in this type of question such as: "Tom, what is your idea?". This type of question can be expected to lead to more communicative use of language but makes lesson planning difficult because the learners' utterances cannot be predicted for a certain topic or goal.

\subsubsection{Display Questions vs. Referential Questions}

Display refers to questions for which the teacher knows the answer and which demand a single or short response of the low-level thinking kind. Referential questions, by contrast, demand more thought and generate a longer response and for which the teacher does not know the answer in advance (Brown, 2001: 171).

\subsubsection{Display Questions}

Suppose you ask your students something you already know. The answer will not satisfy the criterion of providing information. For instance, if you hold up your marker and ask students "What is this?" the answer will not solve a problem. Even less valuable are those questions to which the answers are provided beforehand. Some teachers give their students the information and then try to ask them questions. For example, "This is a marker. What is this?"; such questions can test the students' memory, not their comprehension. In addition such questions are not in harmony with conversational maxims (unwritten rules about conversation which people know and which influence the form of conversational exchanges) which is agreed by many researchers (Widdowson, 1990).

\subsubsection{Referential Questions}

Real language does not consist only of questions from one party and answers from another. Real language circles around referents or world knowledge in order to create messages and therefore is not form-based but meaning-based. Thus, questions in the language classrooms should be Referential or meaning-based, and not focus only on form. (Talebinezhad, 1999). The following examples are meaning-based questions: 


\section{Examples (1):}

1. What would you do if you saw a burglar in your house late at night?

2. How do you spend your holiday?

\section{Examples (2):}

T: Last week we were reading “Kee Knock Stan”[ title of a story]. What is "Kee Knock Stan?" Janice. (Display Question)

P: I cannot understand.

T: Yes.

T: What do you think the postman at the post office would do?

(Referential question)

P: I think I would divide it if the letters are to Hong Kong or other places.

T: Yes, I think that's a sensible way, right? Good. (Tsui, 1995 cited in

Nunan, 2001:122).

It has been suggested that one way for teachers to make classes more communicative is by asking fewer Display questions and more Referential questions.

\section{Method}

\subsection{Research Question and Hypothesis}

The major purpose of this study was to examine teacher/learner interactions in task based settings, to find out what was going on in different contexts of classrooms, and to examine which factors could increase or motivate meaningful teacher/learner interactions. Specifically, the following research question is posed:

'Is there more negotiation of meaning when the teacher switches from asking 'Display to Referential Questions' in teaching English to Iraqi EFL learners?"

Accordingly, our main assumption was put forward through the following hypothesis:

There is no significant difference between Display and Referential questions in conducting much interaction and negotiation of meaning in EFL situation.

\subsection{Participants}

Participants in a classroom discourse are usually a teacher and the students. In this research, the learners from six English classes at intermediate level of the English department College of Languages University of Baghdad served as convenient samples for the study. The EFL learners were at different ages, between 16 and 28, female . The number of learners in each class was between 45 and 65. 6 teachers (of both sexes) were chosen. The teachers had adequate experience of teaching English as a foreign language in Iraq

\subsection{Instrumentation}

To meet the purpose of the study, the following instruments were used:

1. A T.V. set for observing the classes

2. Small cameras which were fixed in the corner of the ceiling of the Classes

3. A headphone for receiving the voice of the teachers and the learners

4. A video set for recording

5. The required textbook was Interchange, Book 1. Each unit consisted of different sections: Snapshot, Conversation, Grammar, Word power and Reading. Beside the main book, some other supplementary books such as Gone with the Wind - simplified version, Tactics for Listening, What's in a word? were used in the classes.

\subsection{Procedure}

The following steps were followed to accomplish the purpose of the study during the research process:

First, the researchers chose six classes and the recordings were conducted in the researchers' room. In order to obtain authentic data, the teachers were not informed about recording of their classes. After recording, the researchers let them know and asked permission for working on their video-taped classes (The audio and video recordings were conducted simultaneously). There was no instruction to the teachers on using different types of questions (Display and Referential) by the researchers in order to obtain authentic data record. Then, the video and audio-recorded data was viewed and listened to by the researchers several times at home. 
Next, the data was transcribed (those parts which related to using Display and Referential questions). The final stage was analyzing the data in order to find a reasonable answer to the research question. By following a four-part process of Record-View-Transcribe-Analyze (RV T-A), foreign language teachers can use discourse analytic techniques to investigate the interaction patterns in their classrooms and to see how these patterns promote or hinder opportunities for learners to practice the target language. This process allows language teachers to study their own teaching behavior- the frequency, distribution, and types of questions they use and their effects on the learners' responses.

\section{Results}

To answer the research question, the researcher implemented the (R-V-T-A) method in order to observe the frequency use of two types of questions (Display and Referential) which were used by the teachers. After collecting the data, a transcribing technique was employed. Transcribing is a tool commonly used by researchers, both those concerned with the study of language and those concerned with exploring other dimensions of everyday life through language.

We should consider that a transcript is a text that re-presents an event; it is not the event itself. After data collection, the observed patterns were analyzed with reference to earlier studies, first, to find and reveal noticeable generalizations and patterns in teachers' questioning behavior and EFL classroom interaction and second, to verify the hypothesis.

\subsection{Quantitative Results}

Two groups of questions were randomly selected from among the obtained data for statistical analysis. The amount of time each question resulted in classroom interaction was measured (in minutes); then, they were added up; and a mean was calculated for each type:

RQ-mean= 1.8 , DQ-mean= 0.87 minutes). The level of confidence showed the degree of confidence, which the researchers could have in their judgment. The conventional level of confidence for rejecting the null hypothesis or confirming substantive "t-value" was examined on the basis of the size of the sample. The size of the sample was considered in terms of the degree of freedom (d.f) which was the sum of the number of questions that is the total number of Referential and Display questions minus 2 (d.f= NR-ND-2) ( Hatch and Farhady, 1982).

Table 1. The amount of interaction caused by two question types.

\begin{tabular}{lllll}
\hline question type & Number & interaction mean & SD & t-observed \\
\hline RQ & 10 & 1.8 & 0.99 & 2.735 \\
DQ & 8 & 0.87 & 0.44 & \\
\hline
\end{tabular}

At this point, all we needed was the critical value for " $\mathrm{t}$ ", since there were two groupsof questions, the total of d.f was 16. The "t-value" needed for our selected significance level of 0.05 is 2.120 . Fortunately, our "t-value" is enough above the "t-critical" that we are quite safe in rejecting the null hypothesis. Comparing the two means, it was seen that the observed results were statistically significant. That is, there was a difference between Display and Referential questions in conducting more interaction in EFL situations.

\subsection{Qualitative results}

The study was not confined to answering the research question; rather, during the data collection procedure, a number of patterns of classroom interaction and questioning were explored, which will be presented here.

1. Teachers ask a number of questions -- mostly Referential -- before they start to work directly on Snapshot, Conversation, Listening, and Reading parts. These questions usually help the learners warm up for the task, and get familiar with the topic of different parts in the textbook.

2. Contrary to what is commonly thought about Display questions, said to elicit short or even one-word answers (e.g. Brock, 1986, cited in Nunan, 1989), sometimes a display question may cause learners to give, for instance, a two/three-minute answer, though we may not consider it as interaction.

3. Almost all the questions asked by teachers while working on the exercises were display. Perhaps due to the accuracy-focused nature of grammar exercises, they do not seem to have led to interactionor speaking practice.

4. Not all of the teachers made equal use of Display or Referential questions. This seems to be a natural incidence since not all teachers think alike, or teach in the same way.

5. Most of the Display questions asked by teachers concerned textual information, e.g. comprehension checks, meaning of words, idioms, re-telling of the story book; while most of the Referential questions concerned personal information or experiences - like feeling, family, ideas, e.g. on society, crime, occupation, future, education, etc.

6. In observed classes, in some cases, interaction was seen without the teachers asking any question. In other words, wherever the topic was interesting, learners tended to speak more.

7. Not all answers given by the learners for Referential questions were long and complex; on the contrary, it was observed that lots of grammatical mistakes were made by the learners and simple answers were given. 
8. The question asking was not just from the teachers, the questions asked by the learners made an interaction between learner-teacher or between learner-learner.

9. Learners who were less willing to participate were usually encouraged, or forced, to speak when asked to speak. Some learners are less confident or are shy but they also participate when the teacher gives them a turn.

\section{Conclusion}

The study focused on what is going on in the classroom, especially on teachers' questioning behavior - what kind of questions they ask, for what purposes, and so on in the context of Iraqi language learners (EFL). Classroom processes are extremely complex; it would be simplistic to think that an observer can fully understand what is going on in the classroom by observing and analyzing a number of lessons. Through observation, it was found that display questions outnumbered Referential ones.

It was observed that Referential questions made more classroom interaction. Johnson and Johnson (1998) cite Swain (1985), who argues that output may be an important factor in successful second language learning /acquisition. She suggests that output creates the necessity for the learner to perform a syntactic analysis of the language. She notes that comprehending the input or getting the message is possible without such an analysis. Producing one's own message, on the other hand, may force the learner to pay attention to the means of expression in order to convey his/her intended meaning. If it is true that such questions increase the amount of learner output, and if output leads to better learning, then questions can be an important tool in the language classrooms, especially in those EFL contexts where the classroom provides the only opportunity to produce the target language.

On the other hand, according to Skehan, cited in Candlin and Mercer (2001), we have to accept that speaking does not come "for free" simply through listening to comprehensible input. So teacher/learner interaction occupies a continuum between Display and Referential questions, and the role of a teacher in question asking is a crucial matter. Question asking must be done purposefully, so teachers should switch from closed discourse to more open discourse in order to create autonomous learner discourse in the classrooms. Moreover, teachers can increase the amount of interaction in their classes by applying two factors: humor and interest. A learner will be more eager when s/he finds the teacher paying attention and interested in the answer.

It would be dangerous to generalize that Referential questions are most useful for language learning or Display are useless. Each context requires an appropriate strategy for itself. Allwright and Bailey (1991) maintain that it is a dangerous simplification to suggest that verbal interaction in the classroom is just a case of "the more, the merrier".

They add that: "there may be times when teacher's desire to get students to interact verbally can be counterproductive. Rather, it is important for teachers to adjust their teaching styles to learners' strategies"

\section{References}

Allwright, D. and Bailey, K.M. (1991). Focus on the language classroom. Cambridge: Cambridge University Press. Brown, H.D (2001). Teaching by principles (2nd Ed.). London: Longman.

Brualdi, A.C. (1998). Classroom questions, Retrieved on May 30, 2005, from http:// PAREonline.net/getrn.asp.

Candlin, C., and Mercer, N. (2001). English in its Social Context. A Reader. London: Routledge.

Chang, D. (1999). Classroom as discourse communities, Retrieved on April, 20, 2005, from www.teachers.net/gazette/Ju102/change.html.

Chastain, K. ( 1988). Developing second language skills: Theory and practice. Orlando, Florida: Harcourt Brace Jovanovich, Inc.

Chaudron, D. ( 1988). Second language classrooms. Cambridge: Cambridge University Press.

Ellis, R. (1990). Instructed second language acquisition. Oxford and Cambridge: Blackwell.

Hatch, E. and Farhady, H. (1982). Research design and statistics for applied linguistics. Rowley, Massachusetts: Newbury House.

Hussain, N. (2003). Helping EFL/ESL students by asking quality questions. Retrieved on March 18, 2004, from http://iteslj.org/Techniques/Hussain-Questions.html.

Johnson, K. and Johnson, H. (1998). Encyclopedic dictionary of applied linguistics. UK: Blackwell. Longman dictionary of American English (2nd ed.). (2000). London: Pearson.

McCarthy, M. (1991). Discourse analysis for language teachers. Cambridge: Cambridge University Press.

Nunan, D. (1989). Understanding language classroom. Cambridge: Prentice Hall.

Nunan, D. (1991). Language teaching methodology. London: Prentice Hall.

Nunan, D. (1993). Introducing discourse analysis. London: Penguin English.

Oberli, C. (2003). Questioning and feedback in the interactive classroom. Retrieved on March 14, 2005, from http://www.cels.bham.ac/uk/resources/essays/oberliM1A.pdf. 
Richards, J.C., Platt, J., and Platt, H. (1992). Dictionary of language teaching and applied linguistics. London: Longman.

Shomoossi, N. (2004). The effect of teachers' questioning behavior on EFL classroom interaction. Retrieved on May 15, 2005, from www.readingmatrix.com/articles/shomoossi/ article volume 4.number2.

Suter, C. (2001). Exploring teachers' questions and feedback. Retrieved on September 10, 2004, from http://www.cels.bham.ac/uk/resources/essays/suter1.pdf.

(2002). Analyzing spoken discourse in the EFL classroom. Retrieved on September 20, 2004, from http://www.cels.bham.ac/uk/resources/essaus/suter2.pdf.

Talebinezhahd, M.R. (1999). Effective questions. Retrieved on March 2, 2005 from www.exchange.state.gov/forum/vols/vol37/no2/p20.html.

Ur. P. (1996). A course in language teaching. Oxford: Oxford University Press.

van Lier, L. (1988). The classroom and the language learner. London: Longman.

Widdowson, H.G. (1984). Explorations in applied linguistics 2. Oxford: Oxford University Press.

Widdowson, H.G. (1990). Aspects of language teaching. Oxford: Oxford University Press.

\section{Appendices}

\section{Sample Referential and Display Questions}

\section{Sample Referential Questions used in the Statistical Analysis}

\section{Example 1:}

T: What can be done to reduce unemployment?

L: I think the best way... about young people.... We know about their interests ....

Which fields they are interested and help them to increase their talents about that and after that ...... make a ..... if for example we give a little money for them. They can open their own business and be very successful at their business.

\section{Example 2:}

T: What are the best ways to stop drug trafficking?

L: To create more jobs for the unemployment.... Because the number of unemployment people be increased and there is no job and inflation.... Be most problem and you have to work because of your life... because you need to eat.... to put on some clothes ... you have to go to bad ways because of that it is good to provide more jobs.

\section{Example 3:}

T: What is the best way to lesson poverty?

L: To provide more jobs and after that give money for that kind of person to open jobs.

For example they know how to make food but they don't have any ability to open their own business.

\section{Example 4:}

T: What are the reasons people eat so much fast food?

L: I think they are delicious.

\section{Sample Display Questions used in the Statistical Analysis}

\section{Example 1:}

T: What does "perpetual" mean?

L: Forever.

\section{Example 2:}

T: Have you heard about "Global Village"? What does it mean?

L: The entire world is like a village. I think because of communication in the world, we will be connected through Internet and it is like a global village.

\section{Example 3:}

T: "Catchy Slogan".... You know "Catchy Slogan”?

L: Something that we can remember.

\section{Example 4:}

T: (pointing to the picture in the textbook) What was there in his locker?

L: Credit card... driving license and twenty dollars. 